\title{
THE LIGHT IN THE OLD ENGLISH RHYMING POEM, LINES 1-2
}

The opening lines of the Exeter Book's Rhyming Poem ( $\underline{\mathrm{RP}})$ reflect the generally enigmatic and imagistic approach of this unusual piece of Old English verse, which sustains end-rhyme alongside its alliterative metre throughout. ${ }^{1}$ In doing so, the text is unique in the surviving corpus of Old English poetry, although shorter rhyming passages can also be found in longer poems such as Cynewulf's Elene (1236-50) and Christ II (591-6): ${ }^{2}$

Me lifes onlah se pis leoht onwrah, ond pæt torhte geteoh, tillice onwrah. ${ }^{3}$

That one granted me life, who revealed this light, drew forth that bright [thing], graciously revealed [it]. ${ }^{4}$

Klinck glosses lines 1-2 by stating broadly, 'the speaker introduces his life and associates it with the beneficent power of God'. ${ }^{5}$ Macrae-Gibson sees these lines as reflecting the poem's broader worldview of 'man as a microcosm of the macrocosm' ${ }^{6}$ He builds here on Cross, who earlier identified the same concern in the $\underline{\mathrm{RP}}$ and in Old English writings more widely; so, over the course of the $\underline{\mathrm{RP}} \mathrm{s}$ narrative, 'the poet has both homo and humus continually in his mind' ${ }^{7}$ Cross

\footnotetext{
${ }^{1}$ The RP spans fols $94^{\mathrm{r}-95^{\mathrm{v}}}$ in the Exeter Book and is edited and translated by O. D. Macrae-Gibson, The Old English Riming Poem (Cambridge, 1983), who suggests a late date on linguistic and literary grounds (1-3). Most previous scholarship on the $\underline{\mathrm{RP}}$ is concerned in some way with its metrical and lexical eccentricities; see notably D. R. Howlett, 'The Structure of The Rhyming Poem', Neuphilologische Mitteilungen, lxxix (1978), 330-2, and James Earl, 'Hisperic Style in the Old English "Rhyming Poem"', PMLA, cii (1987), 187-96.

${ }^{2}$ Cynewulf's Elene, ed. P. O. E. Gradon (Exeter, 1977); Christ II, in George Philip Krapp and Elliott Van Kirk Dobbie (eds), The Exeter Book, The Anglo-Saxon Poetic Records (ASPR), 3 (London, 1936), 15-27. On rhyme in Old English verse, see, e.g., Macrae-Gibson (ed. and trans.), Riming Poem, 21-2. E. G. Stanley, 'Rhymes in English Medieval Verse: From Old English to Middle English', in Edward Donald Kennedy, Ronald Waldron and Joseph S. Wittig (eds), Medieval English Studies Presented to George Kane (Woodbridge, 1988), 19-54.

${ }^{3}$ Macrae-Gibson (ed. and trans.), Riming Poem, lines 1-2, punctuation modified. In 2a I have not kept Macrae-Gibson's emendation of onwrah to onwreah (a variant form of the same verb), considering other end-line repetitions in the text (lines 57-8 and 84-5). Abrams sees these as suggestive of an exemplar arranged as if Latin verse: 'The Errors in “The Rhyming Poem"', RES, n.s. lviii (2007), 1-9. ${ }^{4}$ Following Klinck (ed.), Elegies, 145-6, I take geteoh in 2a as a variant of geteah. Translations my own, after Klinck; Macrae-Gibson (ed. and trans.), Riming Poem; Robert E. Bjork (ed. and trans.), Old English Shorter Poems. Volume II, Wisdom and Lyrics, Dumbarton Oaks Medieval Library, 32 (Cambridge, MA, London; 2014), 91-7; Richard North, Joe Allard and Patricia Gillies (ed. and trans.), The Longman Anthology of Old English, Old Icelandic and Anglo-Norman Literatures (Harlow, 2011), 223-31.

${ }^{5}$ 'The Riming Poem: Design and Interpretation', NM, lxxxix (1988), 266-79, at 272.

${ }^{6}$ Macrae-Gibson (ed. and trans.), Riming Poem, 38.

7 J. E. Cross, 'Aspects of Microcosm and Macrocosm in Old English Literature', in Studies in Old English Literature in Honor of Arthur G. Brodeur, ed. Stanley B. Greenfield, Comparative Literature,
} 
dwells in particular on the idea of the world in decline, ageing into physical and moral decrepitude.

It has not previously been suggested that the opening lines of the poem may draw from more specific contemporary models of the beginnings of human life, including notably Augustine's alignment of the infancies of the individual, humanity, and Creation. ${ }^{8}$ His account in De Genesi contra Manichaeos places key emphasis on the experience of light:

Primordia enim generis humani, in quibus ista luce frui coepit, bene comparantur primo diei quo fecit Deus lucem [...] quia unusquisque homo cum primo nascitur, et exit ad lucem, primam aetatem agit infantiam. Haec tenditur ab Adam usque ad Noe generationibus decem. 9

For the beginnings of the human race, in which it began to enjoy this light, can well be compared to the first day on which God made the light [...] For every man, when he is first born and comes into the light, passes through the first age, infancy. This age extends from Adam to Noah over ten generations. ${ }^{10}$

The RP lines 1-2 similarly hold the beginning of life in the world and the revelation of light in close relation. Cross makes some reference to Augustine, primarily stressing his ambivalent relationship with the idea of the deteriorated world. ${ }^{11}$ Augustine's overall formulation of the six ages of man, the world and the Creation week (brought up to seven ages by the timeless state after death) was nonetheless the 'ages of man' narrative most influential across the medieval period. ${ }^{12}$ Isidore and Bede are both guided by Augustine in their six-age accounts. ${ }^{13}$

14 (Eugene, OR, 1962), 1-22, at 12-3. See also G. V. Smithers, 'The Meaning of The Seafarer and The Wanderer (continued)', MAE, xxviii (1959), 1-22, at 8.

8 This is articulated most clearly in De Genesi I.xxiii.35-41, in Jacques-Paul Migne (ed.), Patrologia Latina Database (PL), 221 vols (Paris, 1844-65; Cambridge, 1996-2008), XXXIV, cols 190-3, and De diversis quaestionibus, lviii.40-80, in A. Mutzenbecher (ed.), Sancti Aurelii Augustini De diversis quaestionibus octoginta tribus; De octo Dulcitii quaestionibus, Corpus Christianorum Series Latina (CCSL) XLIVA (Turnhout, 1975), 106.

${ }_{9}^{9}$ Augustine, De Genesi I.xxiii.35, PL, XXXIV, col. 190.

${ }^{10}$ Roland J. Teske (trans.), On Genesis: Two Books on Genesis against the Manichees and On the Literal Interpretation of Genesis: An Unfinished Book, The Fathers of the Church, 84 (Washington, D.C., 1991), 83-4.

11 Cross, 'Aspects of Microcosm', 6, 9.

12 J. A. Burrow, The Ages of Man: A Study in Medieval Writing and Thought (Oxford, 1986), 80-5; Elizabeth Sears, The Ages of Man: Medieval Interpretations of the Life Course (Princeton, NJ, 1986), 54-69. For evidence of De Genesi in Anglo-Saxon England see Michael Lapidge, The Anglo-Saxon Library (Oxford, 2005), 200, 285.

${ }^{13}$ Isidore of Seville, Isidori Hispalensis Episcopi etymologiarum sive originum libri XX, W. M. Lindsay (ed.), 2 vols (Oxford, 1911), XI.ii.1-8; Differentiae, ii.19 in Migne (ed.), PL, LXXXIII, col. 81. Bede, De temporum ratione, chs 10, 66, in Migne (ed.), PL, XC, cols. 520-73; (without the creation week analogy) De temporibus liber, ch. 16, ed. Charles W. Jones, Bedae opera de temporibus (Cambridge, 1943), 303. See further Paul Archambault, 'The Ages of Man and the Ages of the World: A Study of Two Traditions', Revue des étude augustiniennes, xii (1966), 193-228. 
The alliance between dawning light and dawning apprehension of the world makes another appearance in an age scheme current in the tenth century, Gregory's five-age model, which itself builds on Origen's interpretation of the 'Parable of the Vineyard' in Matthew: ${ }^{14}$

Mane quippe intellectus nostri pueritia est. Hora autem tertia adolescentia intellegi potest, quia quasi jam sol in altum proficit, dum calor aetatis crescit. Sexta vero juventus est, quia velut in centro sol figitur, dum in ea plenitude roboris solidatur. Nona autem senectus intelligitur, in qua sol velut ab alto axe descendit, quia ea aetas a calore juventutis deficit. Undecima vero hora ea est aetas quae decrepita vel veterana dicitur[.] ${ }^{15}$

Morning is the childhood of our understanding. The third hour can be taken as our youth, because the sun is advancing on high as the heat of age increases. The sixth hour is that of young adulthood, because when we reach our full strength it is as if the sun is in the centre of the heavens. The ninth hour we take to be old age, because like the sun descending form its zenith, this age lacks the warmth of youth. The eleventh hour is the age that is called infirm or old[.. $]^{16}$

Elfric adapts Gregory's account of the five ages into the vernacular, supplying Old English age terms for each Latin label. ${ }^{17} \mathrm{He}$ follows Gregory very closely for the most part, but diverges subtly in places. Emphasis is, for instance, placed on increasing and decreasing 'strength' rather than 'heat':

Witodlice ures andgites merigen is ure cildhad. Ure cnihthad swylce underntid, on pam astihð ure geogoð, swa swa seo sunne deð ymbe pære ðriddan tide. Ure fulfremeda wæstm swa swa middæg, for ðan ðe on midne dæg bið seo sunne on ðam ufemestum ryne stigende, swa swa se fulfremeda wæstm bið on fure strencðe peonde. Seo nontid bið ure yld, for ðan ðe on nontide asihð seo sunne, and ðæs ealdigendan mannes mægen bið wanigende. Seo endlyfte tid bið seo forwerode ealdnyss pam deaðe genealæcende, swa swa seo sunne setlunge genealæhð on pæs dæges geendunge. 18

\footnotetext{
${ }^{14}$ Commentary on Matthew, in Jacques-Paul Migne (ed.), Patrologia Graeca, 161 vols (Paris, 18571866), XIII, cols 1359-60.

${ }^{15}$ XL Homiliarum in Evangelia, Homily XIX, in Migne (ed.), PL, LXXVI, col. 1155.

${ }^{16}$ Modified from David Hurst (trans.), Gregory the Great: Forty Gospel Homilies (Kalamazoo, MI, 1990), Homily XI, 79.

${ }^{17}$ See Burrow, Ages of Man, 62.

${ }^{18}$ Dominica in Septuagesima, lines 90-101, in Malcolm Godden (ed.), ÆElfric's Catholic Homilies: The Second Series: Text, EETS, s.s. 5 (Oxford, 1979), punctuation modified.
} 
Certainly, the morning of our understanding is our cildhad. Our cnihthad is like the third hour, on which our geogod rises, just as the sun does at that third hour; our fulfremeda wæstm ('completed growth) is just like midday, for at midday the sun is ascending to its uppermost course, just as the fulfremeda wæstm is increasing to its full strength. The ninth hour is our yld, for on the ninth hour the sun declines, and the strength of the ageing man is waning. The eleventh hour is forwerode ealdnyss, approaching death, just as the sun approaches setting at the end of the day.

Ælfric slightly rearranges the formulation of the first phase. While Gregory glosses the literal 'morning' (mane) by a comparison with intellectual infancy ('morning is the childhood of our understanding'), for Ælfric, the morning is figurative, of the mind, occurring in the time of infancy: 'the morning of our understanding is our cildhad'. His 'morning' is thus bound even more closely with the idea of 'understanding' or 'perception'. ${ }^{19}$

In its opening expression of the coming of light and consciousness of light, I wish to suggest that the $\underline{\mathrm{RP}}$ may be engaging with more specific scripts of human ageing than the general motion of decaying microcosm and macrocosm identified by Cross. This would be consistent with details included in other parts of the poem: Macrae-Gibson has previously suggested an analogy with the clothed and cared-for child of The Fortunes of Men lines 3-4 in the colourful garments mentioned in the $\underline{\mathrm{RP}}$ lines 3-4. ${ }^{20}$ Other references to age-appropriate experiences may now more clearly be seen in the poem's references to building strength: the speaker describes being praised and protected 'while I was in strength' ([p]ende wæs ic in mægen, 18b); $\underline{\text { mægen being one of the terms (along with strencðu) that } Æ l f r i c ~ u s e s ~ t o ~ d e s c r i b e ~ t h a t ~}$ force which gathers and disperses over the life course. In a line taken by MacraeGibson as a reference to burgeoning pride, the speaker also says, 'the mind strengthened' ([m]od mægnade, 33a). ${ }^{21} \mathrm{He}$ is 'strong in armaments' ([f] $]$ rom [...] in frætwum, 40) for a substantial amount of time, as he then remarks 'my life was long amid my people' (lif wæs min longe leodum in gemonge, 41). The speaker's people themselves participate in a semantic network of light and contemplation, from the warrior viewing the treasure (16b-18a), to 'happiness' or 'wealth' which 'shone like a beacon' (ead beacnade, 31b). After line 43, encroaching troubles are framed visually: the speaker's heart is 'fearful of departing forms' (heowsipum sceoh, 43b). Finally, in diurnal terms, 'that withdraws in flight at night, what before in the day was precious' ([g]ewited nihtes in fleah/ se ær in dæge wæs dyre, 44b-5a), and the

\footnotetext{
${ }^{19}$ Angus Cameron, Ashley Crandell Amos, Antonette diPaolo Healey, Roy Liuzza, et. al. (eds), The Dictionary of Old English: A-H Online (DOE), web interface by Peter Mielke and Xin Xiang (Toronto, 2016), s.v. and-gyt, s.v., 1.b., 2.

${ }^{20}$ Krapp and Dobbie (eds.), Exeter Book, 154. Macrae-Gibson (ed. and trans.), Riming Poem, 38.

${ }^{21}$ Macrae-Gibson (ed. and trans.), Riming Poem, 8-9, 46.
} 
'arrow-swift day' (flanhred dæg, 72b) exercises a death grip, while 'night comes' (neaht becymed, $73 \mathrm{~b}$ ) to steal away the speaker's homeland. All these references resonate with the solar model of the passage of life, patterned on the course of the day, and characterised by growing and declining strength, proposed by Ælfric after Gregory.

Augustine also aligns iuventus (the age term rendered fulfremeda wæstm, 'completed growth', by Ælfric) with the creation of the sun and moon; the first to be identified with the 'splendor of a kingdom' (splendorem regni) and the second 'the people, obedient to the kingdom' (plebem obtemperantem regno). ${ }^{22}$ Beginning with the reign of David, iuventus is described by Augustine as 'truly king' among the

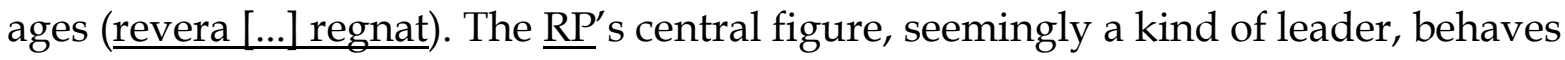
in a manner consistent with this characterisation of socially situated, proud mid-life, especially as his reign ends in moral disgrace on a personal and social level. ${ }^{23}$ The 'evening' (vespera) of Augustine's iuventus 'lies in the sins of the kings for which that people deserved to be taken captive and enslaved' (est in peccatis regum, quibus illa gens meruit captivari atque servire); the subsequent phase (gravitas) is then typified by the Bablyonian exile. ${ }^{24}$ Moral and physical strength is similarly compromised with the passage of time in the $\underline{\mathrm{RP}}$, as the narrative moves towards a wræcfæc ('time of exile', 64a). Davidian echoes have previously been located in the

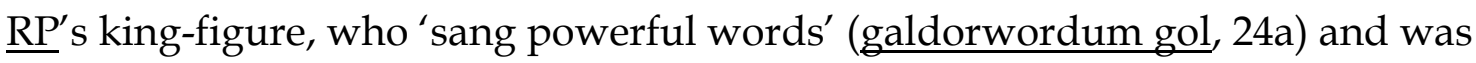
surrounded by the music of the harp (25b, 27-9). ${ }^{25}$ The Old English adaptation of Psalm 50 known as the Kentish Psalm offers an analogue here: in its preface-like section narrating David's life, the 'brave-hearted warrior' (diormod hæled, 1b) falls into a sinful state. ${ }^{26}$ His plurality of faults are described as a 'hoard of sins' (synna $\underline{\text { hord }}$,28a) and a 'hoard of evils' (balaniða hord, 151b). Toswell describes the synna hord construction here as 'noteworthy and original, [...] appear[ing] nowhere else in Old English'. ${ }^{27}$ We might nonetheless see a parallel in the 'burning hoard' (brondhord, 26a) which moves deep in the speaker's feore ('life', 45b) in the RP. In such ways, the various states inhabited by the figure in the RP can be found to

\footnotetext{
${ }^{22}$ De Genesi, I.xxiii.38, in Migne (ed.), PL, XXXIV, col. 191; Teske (trans.), On Genesis, 85.

${ }^{23}$ Karl R. Wentersdorf, 'The Old English Rhyming Poem: A Ruler's Lament', SP, lxxxii (1985), 265-94.

${ }^{24}$ Augustine, De Genesi, I.xxiii.38-9, in Migne (ed.), PL, XXXIV, col. 191; Teske (trans.), On Genesis, 85-6.

${ }^{25} \mathrm{DOE}$, s.v. galdor-word (a hapax), 'words of incantation; or perhaps 'words having power'. The hapax galdorcwide appears on the paten of Riddle 48 (Krapp and Dobbie (ed.), Exeter Book, 205-6), where it seemingly signals the psalms: see DOE, s.v. galdor-cwide, and Megan Cavell, 'Powerful Patens in the Anglo-Saxon Medical Tradition and Exeter Book Riddle 48', Neophilologus, ci (2017), 129-38, esp. 136. Wentersdorf compares these compounds, ultimately considering the RP songs to be 'royal prayers of thanksgiving', comparable with David's psalms of thanks ('Ruler's Lament', 284). ${ }^{26}$ Psalm 50, in Elliott Van Kirk Dobbie (ed.), The Anglo-Saxon Minor Poems, ASPR, 6, 88-94.

${ }_{27}$ M. J. Toswell, The Anglo-Saxon Psalter, Medieval Church Studies, 10 (Turnhout, 2014), 336. Humanity's synna hord is also referred to in line 155a.
} 
engage with more intricate associations attached to the passage of human life than the general idea of declining macro- and microcosm.

Relatedly, these details in the RP also complicate any sense of a simple 'youth and age' binary at work in the poem. Many of the poem's previous scholars have seen this to be its structuring principle (with the major shift occurring at line 43). ${ }^{28}$ So, Smithers sees the first part of the poem as describing 'the exuberant pleasures of youth and affluence', while Macrae-Gibson perceives afflictions later 'in what is evidently his age' ${ }^{29}$ Olsen has pointed out that this division may have been imposed artificially: there are no adjectives in the poem's first section which mention youth. ${ }^{30}$ She does nonetheless detect references to the narrator being 'a man in the prime of life', in such applied adjectives as dryhtlic ('lordly', 39a). ${ }^{31}$ Certainly, the references to strength built, maintained, and then lost as 'the power of the earth grows old' (eorðmægen ealdap, 69a), signal a concept more akin to ÆElfric's fulfremeda wæstm than 'youth'. A re-oriented focus around a peak of strength in the poem would help correct over-hasty diagnoses of a 'youth and age' structure.

The last line of the RP elevates its accumulated references to light, vision and colour, proclaiming that mankind in heaven will be allowed to 'see the true God' (soðne God geseon, 87a). The poem thus uses corporeal and spiritual vision as bookends, opening with brightness revealed in the world, and closing with the higher, direct vision of God. ${ }^{22}$ In doing so, it plays with the same antithesis of light and darkness which Cynewulf also considered appropriate for exploration in rhymed vernacular verse, whether in the form of the interchange between the 'narrowness of the night' (nihtes nearwe, 1239a) and the revelation of learning 'in the form of light' (purh leohtne had, 1245b) in the epilogue to Elene (1236-51), or Christ II's statement that through Christ's intervention, each cwic person may choose: ${ }^{33}$

swa pæt leohte leoht swa ða lapan niht,

\footnotetext{
${ }^{28}$ Howlett ('Structure') argues for the significance of lines 43-4.

${ }^{29}$ Macrae-Gibson (ed. and trans.), Riming Poem, 7.

${ }^{30}$ Alexandra Hennessey Olsen, 'The Heroic World: Icelandic Sagas and the Old-English Riming Poem', Pacific Coast Philology, xiv (1979), 51-8, at 51-2.

${ }^{31}$ Ibid., 'Heroic World', 52.

32 On the sun as worldly parallel to divine light, see, e.g., the OE Soliloquies: 'I am the principle of reason which empowers me to rightly direct you to see God with your mind's eyes, as clearly as you now see the sun with the eyes of the body' ([...] ic eom seo racu de me onhagad de to gerihtreccenne, pæt pu gesyhst myd pines modes eagan god swa sweotole swa pu nu gesyhst myd ðæs licuman æagan ða sunnan), I, T. A. Carnicelli (ed.), King Alfred's Version of St. Augustine's Soliloquies (Cambridge, MA, 1969) 64. See also Hugh Magennis, 'Imagery of Light in Old English Poetry: Traditions and Appropriations', Anglia, cxxv (2007), 181-204.

${ }^{33}$ In the alliterative, rhyming octosyllabic verse of the Carmen Rhythmicum, Aldhelm also makes heavy use of chiaroscuro. R. Ehwald (ed.), Aldhelmi Opera Omnia, Monumenta Germaniae Historica, Auctores Antiquissimi, XV (Berlin, 1919), 523-8). Æthilwald does likewise in his Poem to Aldhelm, in Brent Miles (ed. and trans.), 'The Carmina Rhythmica of Æthilwald: Edition, Translation, and Commentary', The Journal of Medieval Latin, xiv (Turnhout, 2005), 73-117, at 85-88, 94-5.
} 
swa prymmes præce swa pystra wræce[.]

[...] either that light of light, or that detestable night, either power with crowds or the exile of darkness[.]

The $\underline{\mathrm{RP}}$ has previously been described as 'post-Cynewulfian' in its use of rhyme, and in handling the multiplied possibilities for parallelism and antithesis it certainly seems drawn to similar contrasts between well-functioning social cohesion and disordered isolation, aligned with light and darkness. ${ }^{34}$ At the same time, its opening lines implicate a network of associations, attached to the beginning of human life, identifiable as those which guide Bede's interpretation of the sun in De temporum ratione: 'the created Sun which lights up all the stars signifies the true and eternal light which lighteth every man that cometh into the world' ${ }^{35}$ The rest of the poem gains coherence once the resonance of these opening lines has been grasped.

\footnotetext{
${ }^{34}$ Macrae-Gibson (ed. and trans.), Riming Poem, 1.

35 [...] uidelicet sol ille creatus omnium illuminator astrorum aeternam ueramque lucem significat, quae inluminat omnem hominem uenientem in hunc mundum (John 1:9). Charles W. Jones (ed.), Bedae venerabilis opera, pars I: Opera didascalia, vol. II, CCSL, CXXIIIB (Turnhout, 1977), ch. 6, lines 37-9 (292). Faith Wallis (trans.), Bede, The Reckoning of Time (Liverpool, 1999), 25.
} 